\title{
UPAYA MENINGKATKAN PRESTASI BELAJAR AGAMA HINDU MELALUI PENGGUNAAN MODEL PEMBELAJARAN CREATIVE PROBLEM SOLVING
}

\author{
Ni Ketut Sumariyani \\ SD Negeri 3 Sukawati \\ e-mail: ketutsumariyani11@gmail.com
}

\begin{abstract}
Abstrak
Penelitian ini dilaksanakan di SD Negeri 3 Sukawati di Kelas VI A yang kemampuan siswanya untuk mata pelajaran Agama Hindu masih rendah. Tujuan penulisan penelitian tindakan kelas ini adalah untuk mengetahui apakah model pembelajaran Creative Problem Solving dapat meningkatkan prestasi belajar siswa. Metode pengumpulan datanya adalah observasi dan tes prestasi belajar. Metode analisis datanya adalah deskriptif. Dengan hasil yang diperoleh dari penelitian ini adalah model pembelajaran yang diterapkandapat meningkatkan prestasi belajar siswa. Ini terbukti dari hasil yang diperoleh pada awalnya 68,44 pada siklus I meningkat menjadi 74,82 dan pada Siklus II meningkat menjadi 81,37. Kesimpulan yang diperoleh dari penelitian ini adalah model pembelajaran Creative Problem Solving dapat meningkatkan prestasi belajar Agama Hindu siswa kelas VI A SD Negeri 3 Sukawati.
\end{abstract}

Kata-kata kunci : model pembelajaran Creative Problem Solving, prestasi belajar Agama Hindu.

\begin{abstract}
This research was conducted at SD Negeri 3 Sukawati in Class VI A, where the ability of students for Hindu subjects was still low. The purpose of writing this class action research is to find out whether the Creative Problem Solving learning model can improve student achievement. Data collection methods are observation and achievement test. The data analysis method is descriptive. With the results obtained from this study, the learning model applied can improve student achievement. This is evident from the results obtained initially at 68.44 in the first cycle increased to 74.82 and in the second cycle increased to 81.37. The conclusion obtained from this study is the Creative Problem Solving learning model can improve the learning achievement of Hindu Religion students of class VI A SD Negeri 3 Sukawati.
\end{abstract}

Keywords: Creative Problem Solving learning model, Hindu learning achievement. 


\section{Pendahuluan}

Pendidikan merupakan sebuah sistem. Sebagai sistem, aktivitas pendidikan terbangun dalam beberapa komponen, yaitu pendidik, peserta didik, tujuan pendidikan, alat pendidikan, dan lingkungan pendidikan. Semua komponen yang membangun sistem pendidikan, saling berhubungan, saling tergantung, dan saling menentukan satu sama lain. Setiap komponen memiliki fungsi masing-masing dalam rangka mencapai tujuan pendidikan. Aktivitas pendidikan akan terselenggara dengan baik apabila didukung oleh komponen-komponen dimaksud. Fungsi pendidikan sebenarnya adalah menyediakan fasilitas yang dapat memungkinkan tugas pendidikan dapat berjalan lancar, baik secara struktural, maupun secara institusional. Secara struktural menuntut terwujudnya struktur organisasi yang mengatur jalannya proses kependidikan. Secara institusional mengandung implikasi bahwa proses kependidikan yang terjadi dalam struktur organisasi itu dilembagakan untuk lebih menjamin proses pendidikan itu berjalan secara konsisten dan berkesinambungan mengikuti kebutuhan dan perkembangan manusia yang cenderung ke arah tingkat kemampuan yang optimal

Masyarakat dalam penyelenggeraan pendidikan, kadang tidak menyadari bahwa pendidikan terbangun dalam sebuah sistem, sehingga dalam melaksanakan penilaian terhadap aktivitas dan hasil pendidikan, mereka hanya melemparkan tanggung jawab keberhasilan dan kegagalan pendidikan kepada satu kelompok, yaitu guru. Sebagian masyarakat kurang menyadari, bahwa sesungguhnya mereka adalah salah satu komponen yang turut menentukan keberhasilan atau kegagalan pendidikan. Mereka sering melempar tanggung jawab kegagalan pendidikan hanya kepada guru. Pada hal guru hanya merupakan salah satu sub komponen dari komponen dalam sistem pendidikan yang diselenggerakan. Sebagian masyarakat mengkonotasikan pendidikan dengan persekolahan, pada hal keduanya mempunyai perbedaan, walaupun tetap mempunyai hubungan. Pemahaman tentang adanya faktor-faktor determinan dalam pendidikan merupakan hal yang penting, karena kesalahpahaman tentang hal itu, dapat menjadikan kesalahan dalam memberikan penilaian, terutama pada hal-hal yang merupakan kegagalan pendidikan. Tidak jarang ditemukan penilaian yang kurang adil dari masyarakat terhadap sebuah pelanggaran pendidikan yang dilakukan oleh orang-orang yang dianggap terpelajar, dengan mengatasnamakan kegagalan pendidikan, terutama pendidikan persekolahan (formal), tentunya yang menjadi sasaran adalah para guru. Guru/pendidik di sekolah hanya merupakan bagian kecil dari sistem pendidikan, hanya sebagai bagian dari sub sistem pendidik dalam arti luas, yang meliputi pendidik di rumah tangga, pendidik di sekolah, dan pendidik dalam masyarakat (Saat, 2015).

Model pembelajaran Creative Problem Solving (CPS) adalah suatu model pembelajaran yang melakukan pemusatan pada pengajaran dan keterampilan memecahkan masalah, yang diikuti dengan penguatan ketrampilan (Pepkin, 2004). Pemilihan model pembelajaran CPS dalam proses pembelajaran dikarenakan pertama, CPS termasuk kedalam model pembelajaran dengan pendekatan konstruktivistik, dimana yang menjadi pusat pembelajaran adalah siswa (student centered) sehingga dianggap mampu mengaktifkan siswa. Kedua, model pembelajaran CPS dapat digunakan pada siswa dengan kemampuan intelektual yang beragam. Ketiga, model pembelajaran CPS tidak hanya terbatas pada tingkat pengenalan, pemahaman dan penerapan sebuah informasi, melainkan juga melatih siswa untuk dapat menganalisis suatu masalah dan memecahkannya. Keempat, model pembelajaran CPS mudah dipahami dan diterapkan dalam setiap jenjang pendidikan dan tiap materi pembelajaran (Asikin dan Pujiadi, 2008). Mayasari et al. (2013) menyimpulkan bahwa penggunaan model pembelajaran CPS secara signifikan dapat lebih meningkatkan penguasaan konsep dan kemampuan pemecahan masalah siswa dibandingkan dengan penggunaan metode ceramah yang dipadu dengan diskusi (menjawab pertanyaan) atau proses pembelajaran yang lebih banyak didominasi oleh guru. Berdasarkan uraian tersebut, maka penelitian ini dilakukan dengan tujuan untuk meningkatkan kemampuan pemecahan masalah siswa, aktivitas siswa dan kemampuan guru dalam mengelola pembelajaran dengan menerapkan model pembelajaran Creative Problem Solving (CPS) (Udiyah, 2017). 
Siswono (2005) menyatakan bahwa, meningkatkan kemampuan berpikir yaitu menaikkan skor kemampuan di dalam memahami masalah, kefasihan, fleksibilitas dan kebaruan dalam penyelesaian masalah. Menurut Pepkin dalam Supardi (2010), Model pembelajaran CPS merupakan suatu model pembelajaran yang memusatkan pada keterampilan pemecahan masalah, yang diikuti dengan penguatan keterampilan. Proses CPS dikembangkan oleh Sidney Parnes. Proses ini meliputi lima tahap yaitu menemukan fakta, menemukan masalah, menemukan gagasan, menemukan solusi dan menemukan penerimaan (Munandar, 2004). Menurut Hayus, dkk (2013), berdasarkan hasil penelitian menunjukkan bahwa model CPS mendorong siswa untuk dapat menyelesaikan permasalahan yang diberikan oleh guru dengan cara yang kreatif. Selain itu, penelitian yang dilakukan Pudjiadi dan Asikin (2009), menunjukkan bahwa penggunaan model CPS, dapat meningkatkan keterampilan pemecahan masalah peserta didik. Melihat dari hasil observasi awal maka proses berpikir kreatif dapat ditingkatkan dengan menerapkan model CPS. Berdasarkan uraian diatas, maka pada penelitian ini masalah yang dirumuskan yaitu: Bagaimana bentuk langkah-langkah penerapkan model CPS sehingga meningkatkan kemampuan berpikir kreatif peserta didik kelas XI MIA 1 SMAN 1 Bulukumba (materi pokok laju reaksi) (Syamsu, 2016).

Pembelajaran model Creative Problem Solving mempunyai kelebihan antara lain memberikan kepada siswa memahami konsep dengan cara menyelesaikan suatu masalah, membuat siswa aktif dalam pembelajaran, mengembangkan kemampuan berpikir siswa dan membuat siswa dapat menerapkan pengetahuan yang sudah dimilikinya. Model instruksional yang berdasarkan Creative Problem Solving mengembangkan keterampilan berpikir kreatif. Model pembelajaran merupakan alat efisien yang bisa menjadi pedoman untuk mengembangkan kemampuan berpikir. Hal ini dapat meningkatkan nilai nilai posttest siswa yang menggunakan CPS [6]. Sebagai penunjang pelaksanaan kegiatan pembelajaran digunakan media laboratorium virtual yang merupakan alat-alat laboratorium dalam program (software) komputer dan dioperasikan dengan komputer yang dikemas dalam bentuk menarik membuat siswa menjadi tidak jenuh. Dalam proses pembelajaran yang berlangsung siswa menjadi lebih aktif dan mudah memahami konsepkonsep pada materi tersebut. Penggunaan laboratorium virtual dapat meningkatkan prestasi belajar siswa dan memberikan dampak positif bagi sikap siswa tentang materi kimia [7]. Dalam materi Koloid terdapat konsep-konsep yang biasanya hanya disampaikan dalam bentuk kata-kata atau gambar, seperti tentang sifat-sifat koloid dan pembuatan koloid. Dengan adanya percobaan dalam bentuk laboratorium virtual ini siswa dapat memahami konsep dan bukan hanya sekedar menghafal. Pada pembelajaran dengan menggunakan metode konvensional yang diterapkan pada kelas control, pembelajaran menempatkan guru sebagai sumber informasi utama yang berperan dominan dalam proses pembelajaran. Guru mentransfer ilmu kepada siswa sehingga siswa menjadi pasif. Siswa cenderung belajar menghafal dan tidak membangun sendiri pengetahuannya sehingga kreativitas siswa kurang berkembang. Kondisi ini tidak mendukung siswa dalam meningkatkan kemampuan pemecahan masalah. Berdasarkan pengamatan peneliti pada kelas kontrol, tampak bahwa siswa merasa malas dan ngantuk dalam mengikuti proses pembelajaran. Meskipun sesekali disertai tanya jawab, namu tanya jawab tersebut kurang membantu siswa dalam menemukan konsep, karena sebelumnya siswa telah diberi konsep materi oleh guru (Totiana, 2012).

Depdiknas (2003:5) juga menjabarkan aturan yang jelas untuk mencapai tujuan pembelajaran yang diharapkan,yaitu dengan mengembangkan proses belajar yang menyenangkan, memperhatikan keinginan siswa, membangun pengetahuan dari apa yang diketahui siswa, menciptakan suasana kelas yang mendukung kegiatan belajar, memberikan kegiatan yang sesuai dengan tujuan pembelajaran, memberikan kegiatan yang menantang, memberikan kegiatan yang memberi harapan keberhasilan, menghargai setiap pencapaian siswa.

Karena itulah, sebagai agen pembelajaran guru sebagai ujung tombak pendidikan dan keberhasilan pelaksanaan UU Sistem Pendidikan, diharapkan memiliki pengetahuan dan keterampilan yang berhubungan dengan tugas dan tanggung jawabnya selaku guru yang 
profesional. Guru yang profesional harus memiliki seperangkat kompetensi (pengetahuan, keterampilan dan perilaku) untuk mampu menjalankan tugas yang diembannya. Berdasarkan UU no. 14 Tahun 2005 tentang Guru dan Dosen pada Bab IV Pasal 10 ayat (1) menyatakan bahwa Kompetensi guru sebagaimana dimaksud dalam Pasal 8 meliputi kompetensi pedagogik, kompetensi kepribadian,kompetensi sosial, dan kompetensi profesional yangdiperoleh melalui pendidikan profesi.

Sementara menurut Saud (2012: 50) Proyek Pembinaan Pendidikan Guru (P3G) telah merangkum kompetensi guru di Indonesia yang meliputi: (1) menguasai bahan; mengelola program belajar-mengajar; menggunakan media/sumber belajar; menguasai landasan kependidikan; mengelola interaksi belajar-mengajar; menilai prestasi belajar; mengenal fungsi dan layanan bimbingan penyuluhan; mengenal dan menyelenggarakan administrasi sekolah; dan memahami dan menafsirkan hasil penelitian guna keperluan pengajaran.

Beranjak dari apa yang disampaikan oleh Cooper menyangkut masalah profesionalisme guru, Wina Sanjaya juga menyatakan bahwa untuk meyakinkan bahwa guru sebagai pekerjaan professional, marilah kita tinjau syarat-syarat atau ciri pokok dari pekerjaan profesional. (a) Pekerjaan profesional ditunjang oleh suatu ilmu tertentu secara mendalam yang hanya mungkin didapatkan dari lembaga-lembaga pendidikan yang sesuai, sehingga kinerjanya didasarkan kepada keilmuanyang dimilikinya yang dapat dipertanggungjawabkan secara ilmiah. (b) Suatu profesi menekankan kepada suatu keahlian dalam bidang tertentu yang spesifik sesuai dengan jenis profesinya, sehingga antaraprofesi yang satu dengan yang lainnya dapat dipisahkan secara tegas. (c) Tingkat kemampuan dan keahlian suatu profesi didasarkan kepadalatar belakang pendidikan yang dialaminya yang diakui oleh masyarakat, sehingga semakin tinggi latar belakang pendidikan akademis sesuai dengan profesinya, semakin tinggi pula tingkat keahliannya dengan demikian semakin tinggi pula tingkat penghargaan yangditerimanya. (d) Suatu profesi selain dibutuhkan oleh masyarakat juga memiliki dampak terhadap sosial kemasyarakatan, sehingga masyarakat memilikikepekaan yang sangat tinggi terhadap setiap efek yang ditimbulkannyadari pekerjaan profesinya itu (Sanjaya, 2010: 275).

Sementara itu, Ali Idrus menyatakan untuk menghadapi tantangan zaman dengan kemajuan teknologi informasi dan ilmu pengetahuan yang serba cepat dibutuhkan guru profesional yang intelektual dan bermoral. Hal itu sesuai dengan pendapat Giroux (1988) yang disampaikannya bahwa sosok guru yang mampu memunculkan inovasi dalam pendidikan adalah guru yang menurutnya mau terus berkembang dan belajar seumur hidup, tidak pernah puas dengan apa yang dimengerti, mau membawa perubahan, berpikir kritis, rasional bebas mengembangkan pikiran, reflektif, berani membela kebenaran dan keadilan. Dan tidak dibutuhkan guru yang hanya mempertahankan status quo-nya dan menjalankan tugasnya seperti tukang (Idrus, 2009: 157).

Menyadari permasalahan yang sedang dihadapi, untuk mendukung semua yang telah dijelaskan di atas. Guru selaku peneliti yang bertugas di SD Negeri 3 Sukawati mencoba melakukan koreksi dan refleksi atas hasil belajar awal siswa kelas VI A semester I Tahun Ajaran 2018/2019 yang ditemukan pada saat observasi. Rata-rata nilai mata pelajaran Agama Hindu siswa yang diperoleh hanya mencapai 68,44 dengan prosentase ketuntasan belajar sebesar $34,48 \%$. Nilai tersebut ternyata masih jauh dari Kriteria Ketuntasan Minimal (KKM) yang ditetapkan sekolah SD Negeri 3 Sukawati yaitu 75.

\section{Metode}

Tempat Dalam melaksanakan Penelitian Tindakan Kelas, langkah-langkah atau prosedur PTK didasarkan pada model rancangan PTK dari para ahli. Selama ini dikenal berbagai model PTK, namun pada dasarnya terdapat empat tahap yang harus dilalui yaitu (1) perencanan (planning), (2) pelaksanaan (acting), (3) pengamatan (observing), dan (4) refleksi (reflecting). Keempat tahap tersebut merupakan satu siklus dan akan dapat berlanjut kepada siklus kedua, siklus ketiga dan seterusnya sesuai dengan apa yang diinginkan dalam penelitian. 


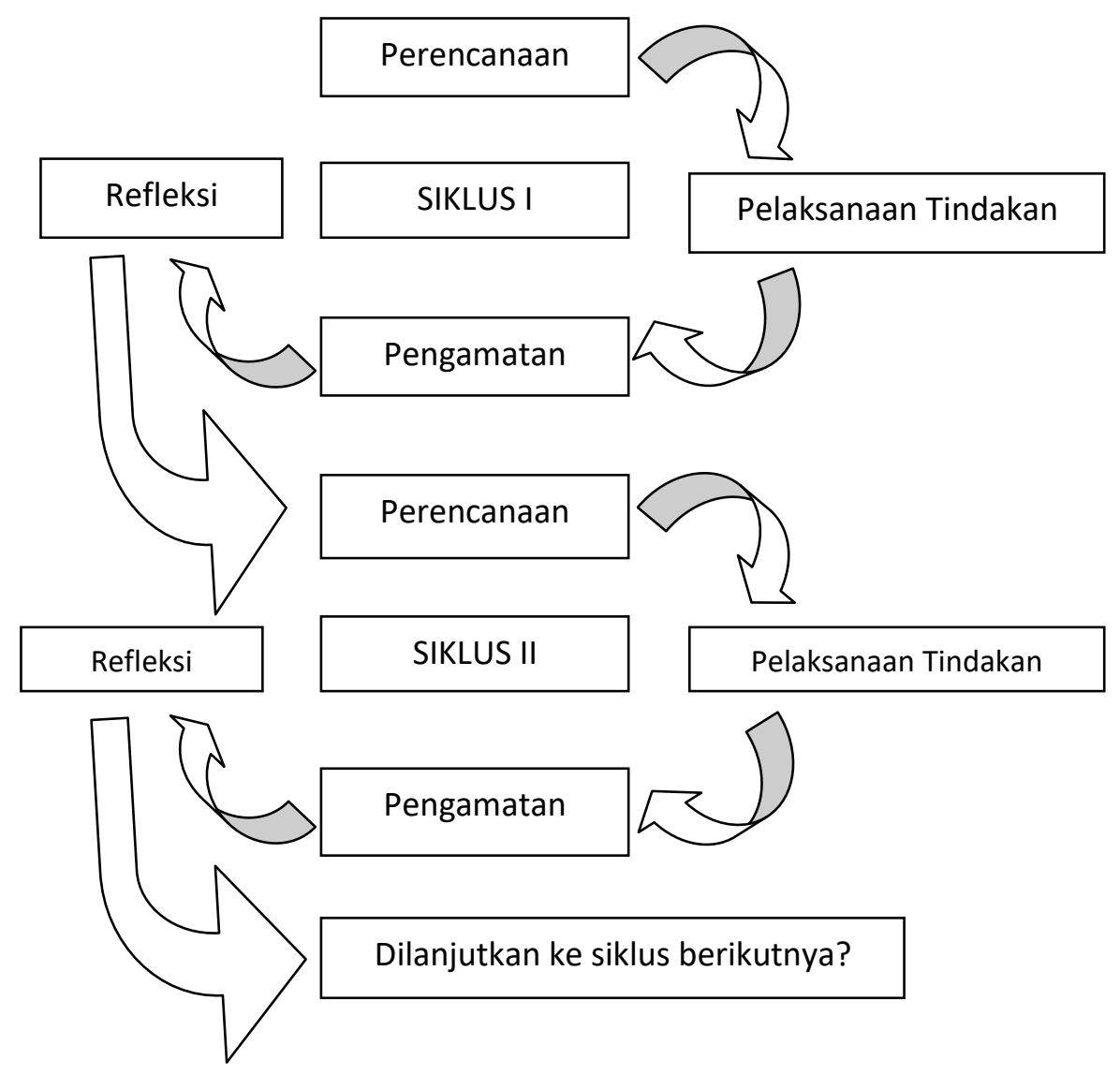

Gambar 1. Gambar Rancangan Penelitian Tindakan Kelas

1. Perencanaan Tindakan

Adapun perencanaan yang dilakukan untuk melaksanankan penelitian tindakan kelas adalah sebagai berikut.

1) Berkoordinasi dengan kepala sekolah untuk melaksanakan penelitian

2) Melakukan refleksi awal dengan melihat hasil belajar Agama Hindu siswa sebelum dilaksanakan penelitian.

3) Melakukan analisis kurikulum untuk mengetahui standar kompetensi, kompetensi dasar dan menyusun silabus yang disampaikan kepada siswa dengan menggunakan pendekatan saintifik berbasis lingkungan.

4) Menyusun Rencana Pelaksanaan Pembelajaran (RPP) dilengkapi LKS yang dirancang. Langkah-langkah pembelajarannya diarahkan pada pendekatan saintifik berbasis lingkungan untuk materi yang diajarkan.

5) Menyusun lembar penilaian dan tes/evaluasi berupa tes hasil belajar dan kuesioner motivasi belajar.

6) Membuat ringkasan materi yang dibahas.

7) Membuat instrumen untuk penelitian tindakan kelas berupa lembar refleksi.

\section{Pelaksanaan Tindakan}

Dalam pelaksanaan ini disusun sesuai dengan tahap pelaksanaan penerapan model pembelajaran Creative Problem Solving dalam mata pelajaran Agama Hindu untuk mengetahui hasil belajar siswa. Pada setiap siklus penelitian terdiri dari 4 kali pertemuan. 3 kali pertemuan untuk melaksanakan proses pembelajaran dan 1 kali pertemuan untuk melaksanakan evaluasi atau tes hasil belajar dan mengukur motivasi belajar siswa. Langkahlangkahnya adalah sebagai berikut. 
1) Persiapan pada awal pembelajaran

Pada tahap ini, kegiatan yang dilaksanakan adalah mempersiapkan perangkat pembelajaran, membentuk kelompok learning komunity, menetukan skor awal, mengatur tempat duduk dan melakukan kegiatan apersepsi.

2) Pelaksanaan pembelajaran

Langkah-langkah dalam pelaksanaan tindakan ini adalah dilaksanakan sesuai dengan Rencana Pelaksanaan Pembelajaran (RPP) yang telah disusun dan disiapkan dengan menerapkan tahap-tahap model pembelajaran Creative Problem Solving

3) Observasi / Evaluasi

Pada pertemuan ke 4, guru melaksanakan tes hasil belajar dan mengukur motivasi belajar siswa. Kegiatan yang dilakukan pada tahap evaluasi yaitu memberikan lembar tes evaluasi kepada siswa yang bertujuan untuk mengetahui hasil belajar siswa dan kuesioner motivasi belajar untuk mengetahui tingkat motivasi belajar siswa setelah dilaksanakannya pembelajaran dengan model pembelajaran Creative Problem Solving. Hasil evaluasi akan menjadi acuan bagi peneliti dalam merancang pembelajaran pada siklus berikutnya (siklus II).

4) Refleksi

Refleksi ini dilakukan untuk melihat dan mengkaji hasil tindakan pada siklus I mengenai hasil belajar Agama Hindu dan motivasi belajar siswa. Hasil kajian tindakan siklus I ini, selanjutnya dipikirkan untuk dicari dan ditetapkan beberapa alternatif tindakan baru yang diduga lebih efektif untuk meningkatkan hasil belajar Agama Hindu. Alternatif tindakan ini ditetapkan menjadi tindakan baru pada rencana tidakan dalam penelitian.

Pengumpulan data dalam penelitian ini menggunakan tes prestasi belajar. Untuk menganalisis data hasil penelitian ini digunakan metode deskriptif. Untuk data kuantitatif dianalisis dengan mencari mean, median, modus, membuat interval kelas dan melakukan penyajian dalam bentuk tabel dan grafik.

Indikator keberhasilan penelitian yang diusulkan dalam penelitian ini pada siklus I dan II mencapai nilai rata-rata 75,00 dengan ketuntasan belajar $85 \%$. dengan KKM yang ditetapkan untuk mata pelarajan Agama Hindu pada SD Negeri 3 Sukawati adalah 75.

\section{Hasil dan Pembahasan}

Pemecahan masalah yang melibatkan proses kreatif disebut pemecahan masalah kreatif (Creative Problem Solving).menurut Treffinger (2005) model pembelajaran Creative Problem Solving disebut sebagai model konseptual mengusulkan tiga komponen proses, yaitu 1) memahami tantangan; 2) menghasilkan gagasan; 3) menyiapkan tindakan. Komponenkomponen proses tersebut terdiri dari enam tahap dimana menekankan adanya keseimbangan dalam menggunakan kemampuan berfikir kreatif dan kritis.

model pembelajaran Creative Problem Solving memiliki tiga komponen. Pertama, komponen memahami tantangan merupakan suatu upaya sistimatis untuk menegaskan, membangun atau berfokus pada suatu usaha pemecahan masalah. Komponen proses kedua yakni menghasilkan gagasan merupakan suatu tahap menghasilkan banyak pilihan yang bervariasi dan tidak biasa sebagai respon terhadap masalah yang ada. Sedangkan komponen proses ketiga adalah menyiapkan tindakan, yakni suatu tahap untuk membuat keputusan, mengembangkan, atau untuk memperkuat alternatif solusi yang telah dipilih, dan untuk merencanakan keberhasilan implementasi aksi.

Data pada awal pembelajaran diperoleh nilai rata-rata 68,44 siswa yang tuntas hanya 10 $(34,48 \%)$ dan yang tidak tuntas tuntas ada 19 orang $(65,51 \%)$ hal ini masih jauh dari harapan tujuan pembelajaran yang ingin dicapai adalah $85 \%$. Hasil pada awal pembelajaran ini masih sangat jauh dari harapan hal ini terjadi karena guru belum menggunakan model pembelajaran dan RPP masih bersifat konvensional. Untuk meninggkatkan hasil belajar siswa kelas VI A semester I SD Negeri 3 Sukawati tahun pelajaran 2018/2019 perlu ditingkatkan dengan 
melakukan perbaikan pembelajaran pada siklus I dengan menggunakan model pembelajaran Creative Problem Solving.

Pada siklus I, hasil yang diperoleh belum mencapai target dari indikator keberhasilan penelitian. Hal ini disebabkan oleh masih belum sempurnanya rancangan pembelajaran yang akan disampaikan guru. Namun pada siklus I sudah menunjukan peningkatan minat siswa dalam mengikuti pembelajaran yaitu dari data awal yang hanya mncapai rata-rata 68,44 meningkat menjadi 74,82 . Sedangkan presentase ketuntasan meningkat dari $34,48 \%$ pada data awal menjadi $68.96 \%$ pada siklus I

Perkembangan peserta didik pada siklus II ini adalah 29 orang siswa yang diteliti, 1 anak yang mendapat nilai di bawah KKM, ada 5 anak mendapat nilai sama dengan KKM dan 23 anak mendapat nilai diatas KKM artinya mereka sudah berkembang sesuai indikator, mereka sudah giat belajar, sudah aktif dalam belajar. Anak-anak ini termasuk anak yang aktif dalam belajar. Dari semua data yang sudah diperoleh tersebut dapat diberi sintesis bahwa semua anak sudah mampu melakukan semua indikator yang diharapkan

Semua hasil yang diperoleh dari awal, siklus I dan siklus II dipaparkan dalam bentuk grafik berikut.

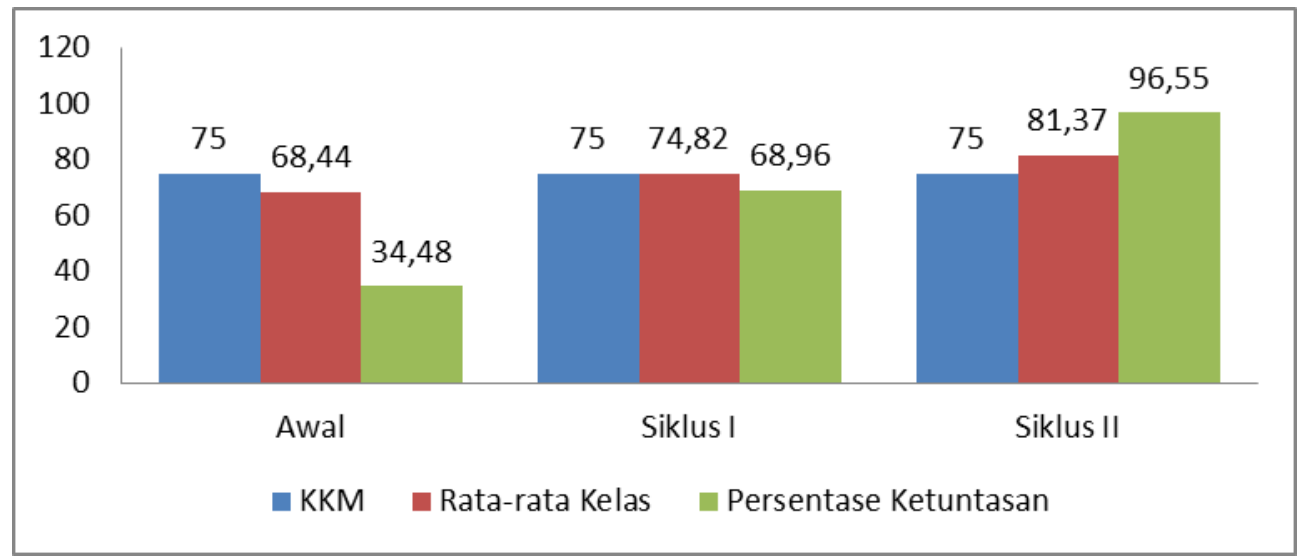

Grafik 1. Grafik Histogram Prestasi Belajar Agama Hindu siswa kelas VI A semester I tahun pelajaran 2018/2019 SD Negeri 3 Sukawati

Hasil penelitian ini diperkuat dengan hasil penelitian yang dilakukan oleh Intan Sagita pada tahun 2018 yang berjudul Penerapan Creative Problem Solving Model untuk Meningkatkan Kemampuan Pemecahan Masalah Fisika Siswa Kelas XI MIA 4 MAN 2 Kota Bengkulu. Hasil analisis data menunjukkan bahwa aktivitas belajar siswa pada siklus I dengan rata-rata skor sebesa 24 (kategori baik), siklus II sebesar 26,5 (kategori baik), dan siklus III sebesar 28 (kategori baik). Kemampuan pemecahan masalah pada siklus I sebesar 71,69 dengan kategori sedang dan ketuntasan belajar secara klasikal 60\% (belum tuntas secara klasikal), pada siklus II kemampuan pemecahan masalah sebesar 78,71 dengan kategori sedang dan ketuntasan belajar klasikal 77,14 (belum tuntas secara klasikal), dan pada siklus III kemampuan pemecahan masalah sebesar 86,94 dengan kategori tinggi dan ketuntasan belajar secara klasikal 88,57 (tuntas secara klasikal). Bedasarkan hasil penelitian dapat disimpulkan bahwa penerapan model creative problem solving dapat meningkatkan aktivitas belajar dan kemampuan pemecahan masalah siswa.

\section{Simpulan dan Saran}

Berdasarkan penelitian yang telah dilakukan, ditemukan bahwa: 1) Dari data awal ada 19 siswa mendapat nilai dibawah KKM dan pada siklus I menurun menjadi 9 siswa dan siklus II hanya 1 siswa mendapat nilai di bawah KKM. 2) Nilai rata-rata awal 68,44 naik menjadi 74,82 
pada siklus I dan pada siklus II naik menjadi 81,37. 3) Dari data awal siswa yang tuntas hanya 10 orang sedangkan pada siklus I menjadi lebih banyak yaitu 20 siswa dan pada siklus II menjadi cukup banyak yaitu 28 siswa.

Paparan di atas membuktikan bahwa model Creative Problem Solving dapat memberi jawaban sesuai tujuan penelitian ini. Semua ini dapat dicapai karena model Creative Problem Solving sangat efektif diterapkan dalam proses pembelajaran yang mengakibatkan siswa aktif, antusias dan dapat memahami materi yang diajarkan sehingga prestasi belajar siswa menjadi meningkat.

Saran yang dapat disampaikan pada penelitian ini adalah sebagai berikut: 1) Bagi guru kelas, apabila mau melaksanakan proses pembelajaran penggunaan model Creative Problem Solving yang telah diterapkan ini semestinya menjadi pilihan dari beberapa model yang ada mengingat model/metode ini telah terbukti dapat meningkatkan prestasi belajar siswa. 2) Bagi peneliti lain, walaupun penelitian ini sudah dapat membuktikan efek utama dari model Creative Problem Solving dalam meningkatkan prestasi belajar, sudah pasti dalam penelitian ini masih ada hal-hal yang belum sempurna dilakukan, oleh karenanya disarankan kepada peneliti lain yang berminat meneliti topik yang sama untuk meneliti bagian-bagian yang tidak sempat diteliti. 3) Bagi pengembang pendidikan, selanjutnya untuk adanya penguatan-penguatan, diharapkan bagi peneliti lain untuk melakukan penelitian lanjutan guna memverifikasi data hasil penelitian ini.

\section{Daftar Pustaka}

Dahar, Ratna Wilis. 1989. Teori-Teori Belajar. Jakarta: Penerbit Erlangga.

Depdiknas .2003. Undang-undang RI No.20 tahun 2003 Tentang Sistem Pendidikan Nasional.

Depdiknas. 2003. Kurikulum 2004 Sekolah Menengah Pertama. Direktorat Jenderal Pendidikan Dasar dan Menengah Direktorat Pendidikan Lanjutan Pertama.Pedoman Khusus Pengembangan Silabus Berbasis Kompetensi Sekolah Menengah Pertama Mata Pelajaran Agama Hindu. Direktorat Jenderal Perguruan Tinggi. Jakarta

Dimyati dan Mudjiono. 2001. Belajar dan Pembelajaran. Jakarta: Dirjen Dikti.

Fabeta.Syamsu, Syari Ahmad. 2016. Penerapan Model Creative Problem Solving (CPS) untuk Meningkatkan Kemampuan Berpikir Kreatif Peserta Didik Kelas XI MIA 1 SMA Negeri 1 Bulukumba (Studi pada Materi Pokok Laju Reaksi). Jurnal Chemica Vo/. 17 Nomor 2 Desember 2016, 63 - 74 .

Hamalik, Oemar. 2002. Psikologi Belajar dan Mengajar. Bandung: Sinar Baru.

Idrus, M. 2009. Metode Penelitian IImu Sosial. Yogyakarta: PT. Gelora Akasara.

Saat, Sulaiman. 2015. Faktor-Faktor Determinan Dalam Pendidikan (Studi Tentang Makna Dan Kedudukannya Dalam Pendidikan) . Jurnal Al-Ta'dib Vol. 8 No. 2, Juli-Desember

Sagita, Intan, dkk. 2018. Penerapan Creative Problem Solving Model untuk Meningkatkan Kemampuan Pemecahan Masalah Fisika Siswa Kelas XI MIA 4 MAN 2 Kota Bengkulu. Jurnal Kumparan Fisika (ISSN 2655-1403) Volume 1 Nomor 3.

Sanjaya, Wina. 2010. Strategi Pembelajaran Berorientasi Standar Proses. Pendidikan. Jakarta: Prenada Media Group.

Saud, UdinSyaefudin. 2012. Pengembangan Profesi Guru. Bandung: A 
Udiyah, Ika Nur Mas. 2017. Penerapan Model Pembelajaran Creative Problem Solving (CPS) terhadap Kemampuan Pemecahan Masalah IPA Kelas VII SMP Negeri 2 Tuban .Jurnal Proceeding Biology Education Conference Vol. 14 (1): 540-544, Oktober 2017

Totiana, Fian. 2012. Efektivitas Model Pembelajaran Creative Problem Solving (Cps) Yang Dilengkapi Media Pembelajaran Laboratorium Virtual Terhadap Prestasi Belajar Siswa Pada Materi Pokok Koloid Kelas Xi Ipa Semester Genap Sma Negeri 1 Karanganyar Tahun Pelajaran 2011/2012 . Jurnal Pendidikan Kimia (JPK), Vol. 1 No. 1 Tahun 2012 Program Studi Pendidikan Kimia Universitas Sebelas Maret. 